\title{
Changes in seagrass communities along the runoff gradient of the Trang river, Thailand
}

\author{
Chadchai Khogkhao $^{\mathrm{a}}$, Ken-ichi Hayashizaki ${ }^{\mathrm{b}}$, Piyalap Tuntiprapas ${ }^{\mathrm{a}}$, Anchana Prathep ${ }^{\mathrm{a}, *}$ \\ a Seaweed and Seagrass Research Unit, Excellence Centre for Biodiversity of Peninsular Thailand, \\ Department of Biology, Faculty of Science, Prince of Songkla University, Hat Yai 90112 Thailand \\ b School of Marine Biosciences, Kitasato University, Kitasato, Minami-ku, Safamihara, Kanagawa, \\ 252-0373, Japan
}

${ }^{*}$ Corresponding author, e-mail: anchana.p@psu.ac.th

Received 24 Sep 2017

Accepted 26 Dec 2017

\begin{abstract}
Seagrasses are widely distributed from coastal estuaries through to deep waters. We examined the spatial pattern in seagrass species composition, biomass, and their relationships with various physical factors: salinity, mean sea level, light extinction coefficient, temperature, grain size (gravel, coarse sand, fine sand, clay), and soil organic matter between dry and rainy seasons along the gradient of Trang river mouth around Talibong Island, Trang province. Ten species were found in an area of $61 \mathrm{~km}^{2}$ in the dry season, whereas only eight species were found in $24 \mathrm{~km}^{2}$ in the rainy season. Halophila decipiens Ostenfeld was the dominant species covering $29 \mathrm{~km}^{2}$ in the dry season. Enhalus acoroides (Linnaeus f. Royle) and H. ovalis (R. Brown) J.D. Hooker extended over a large area. Density, area covered, and biomass decreased in the rainy season for most species. A clear seasonal variation was observed both in physical and chemical parameters as well as seagrass species composition, biomass, and reproduction. Water depth and light intensity were the limiting factors that influenced species composition, biomass, and reproduction.
\end{abstract}

KEYWORDS: salinity, sedimentation, siltation, species composition, biomass, reproduction

\section{INTRODUCTION}

Seagrasses are often associated with estuarine habitats, affected by freshwater runoff ${ }^{1}$. These water runoffs carry sediments from terrestrial to coastal areas, resulting in increased siltation ${ }^{2,3}$. A heavy sedimentation load has a negative effect on seagrasses. For example, experimental burial in Zostera noltii resulted in a decreased shoot density ${ }^{4}$.

Thailand and Southeast Asia are biodiversity hotspots of seagrasses ${ }^{5}$. Seagrasses often occur near river mouths with increasing of flooding events and intense coastal developments in the region ${ }^{2}$. In the Philippines and Thailand, seagrass species richness and community leaf biomass are lower in sediments with high silt and clay contents ${ }^{6,7}$, Enhalus acoroides being the only species remaining in heavily silted sediments ${ }^{7}$. The principal cause of siltation in estuary habitats is runoff from seasonal rains ${ }^{8,9}$. Increasing river flows result in higher sediment loads which reduce light available for seagrasses. This is becoming a critical problem in the tropical regions, where coastal developments are intense ${ }^{2}$. Also, climate change may increase flooding and runoffs ${ }^{10}$.

In estuaries, seasonal trends in the seagrass biomass are often driven by light availability 6,11 .
Seasonal runoffs also result in differing saline regimes, and some species can tolerate changes in salinity. Salinity is an important factor affecting the osmosis pressure in cells, and most seagrasses are adapted to live in constant saline regimes. Thus decreased salinity generally has negative impacts on most seagrasses species, causing biomass declines in the rainy season ${ }^{12,13}$.

The aim of this study is to assess the vulnerability of seagrass community health related to environment along a gradient in the Trang river mouth.

\section{MATERIALS AND METHODS}

\section{Sampling site and environmental factors}

Talibong island in Trang province is the largest seagrass bed in Thailand designated as the first Ramsar site in the country. This site is the largest site for dugong population in Thai waters. Nine species were reported around the island (Enhalus acoroides, Halophila beccarii, H. ovalis, Thalassia hemprichii, Cymodocea serrulata, C. rotundata, Halodule pinifolia, $H$. uninervis, and Syringodium isoetifolium); E. acoroides, C. serrulata, C. rotundata, and $H$. ovalis were often at shallow areas (depth of +0.3 to $-1.9 \mathrm{~m}$ ), while only $H$. ovalis was dominant in 
deep areas (depth of -0.7 to $-2.4 \mathrm{~m})^{11}$. Ten line transects, with a total length of $18 \mathrm{~km}$, were laid out to cover the study area covering a total area around $259 \mathrm{~km}^{2}(18 \mathrm{~km} \times 14.4 \mathrm{~km})$. Light intensity was measured with an Underwater Quantum Sensor (LI192, LI-COR, Lincoln, NE, USA) as $\mu \mathrm{mol} \mathrm{m}^{-2} \mathrm{~s}^{-1}$. The light extinction coefficient $K_{\mathrm{d}}$ was calculated as the difference between the irradiance above the water and irradiance at the level of the seagrass canopy, or sediment surface if seagrass was absent, following this Beer-Lambert equation:

$$
K_{\mathrm{d}}=\left(\ln \frac{I_{z}}{I_{0}}\right) \frac{1}{z}
$$

where $I_{0}$ and $I_{z}$ are light intensity at depths of 0 and z, respectively.

A Hydrolab multiparameter water quality probe (MS5, Hach Environmental, Loveland, CO, USA) was deployed to measure salinity, temperature, and water depth. Thus water depth was measured at different times in each station and re-calculated with mean sea level (MSL) as the standardized depth. Salinity was classified to mixohaline (0.5$30 \mathrm{psu}$ ) and euhaline (30-40 psu) associated with river discharge. Sediments were collected using sediment cores $4.5 \mathrm{~cm}$ diameter, $25 \mathrm{~cm}$ for analysis of grain size and organic matter. The sediments were dried at $60^{\circ} \mathrm{C}$ for $48 \mathrm{~h} ; 20 \mathrm{~g}$ of sediment was sieved on a sieve shaker to classify the grain size following Wentworth ${ }^{14}$. Sediment grain size was classified as coarse sand $(250 \mu \mathrm{m})$, fine sand (63$250 \mu \mathrm{m})$, and mud $(63 \mu \mathrm{m})$. Sediment $(5 \mathrm{~g})$ was combusted in a furnace at $550^{\circ} \mathrm{C}$ for $4 \mathrm{~h}$ to measure the organic matter content $(\mathrm{OM})$. The $\mathrm{OM}$ was calculated from the weight loss of the dry sediment on ignition ${ }^{15}$.

\section{Plants measurement}

Seagrasses were observed at 77 sites distributed in a grid in the studied seagrass bed (Fig. 1). At each permanent station, five replications of $0.25 \mathrm{~m}^{2}$ quadrats were haphazardly placed by scuba divers in the dry season (February in 2014) and the rainy season (November in 2014). In each quadrat, the total species percentage cover, the percentage cover and the number of shoots and reproductive structure were examined for each seagrass species. The plants were collected and in the laboratory, they were separated to above-ground parts (leaf and leaf sheath) and below-ground parts (rhizome and root) before drying at $60^{\circ} \mathrm{C}$ for $48 \mathrm{~h}$ to determine dry weight.

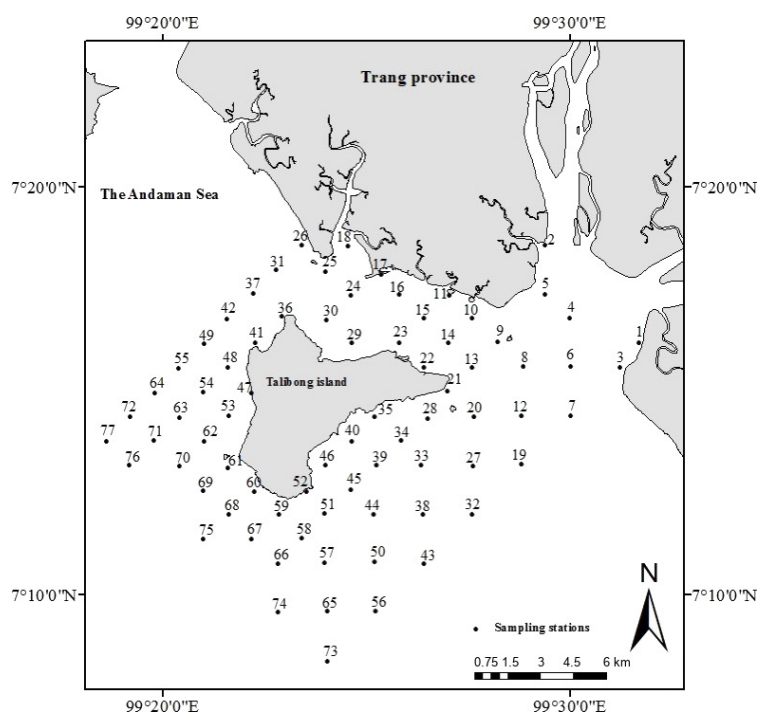

Fig. 1 Map of study area around Talibong island. Circles indicate sampling stations.

\section{Data analyses}

Data from 77 permanent stations were interpolated using IDW algorithm to generate contours of all species and separately for each species in the study area of $215.85 \mathrm{~km}^{2}$. One-way ANOVA was used to test the differences in physical and chemical parameters between seasons. The seagrass parameters (percentage cover, density, above-ground biomass, below-ground biomass, fruiting, and flowering) did not meet the assumption of ANOVA, thus a KruskalWallis test was used to test the differences in those seagrass parameters between species, salinity gradients, and seasons. Canonical correspondence analysis (CCA) was conducted to determine the multivariate correlations between the seagrass distribution and the physical and chemical parameters, using PC-ORD 5.0. Monte Carlo tests with 999 permutations were used in this analysis, and the joint plot only variables with values 0.05 . The relationships between physical and chemical parameters and seagrass percentage cover, density, aboveground biomass, below-ground biomass, flowering, and fruiting were tested using stepwise multiple regressions, using SPPS 13.0.

\section{RESULTS}

\section{Environmental factors}

The average light intensity, $K_{\mathrm{d}}$, salinity, coarse sand, and silt differed between dry and rainy season, whereas there were no significant differences in water depth, gravel, fine sand, and OM between 
Table 1 Summary of statistical analysis for one-way ANOVA testing effects of seasons on all variables.

\begin{tabular}{|c|c|c|c|c|c|c|}
\hline \multirow[t]{2}{*}{ Variables } & \multirow[t]{2}{*}{ Transf." } & \multicolumn{2}{|c|}{ Dry season } & \multicolumn{2}{|c|}{ Rainy season } & \multirow[t]{2}{*}{$F$-values } \\
\hline & & Min-Max & Mean \pm SE & Min-Max & Mean \pm SE & \\
\hline light intensity $\left(\mu \mathrm{mol} \mathrm{m} \mathrm{m}^{-2} \mathrm{~s}^{-1}\right)$ & $\sqrt{x}$ & $0-1706.8$ & $567 \pm 52$ & $0-718.20$ & $110 \pm 18$ & $83.44^{+}$ \\
\hline$K_{\mathrm{d}}(\mathrm{m})$ & $\sqrt{x}$ & $0.13-14.73$ & $6.02 \pm 0.58$ & $0.10-6.53$ & $1.37 \pm 0.20$ & $71.13^{\ddagger}$ \\
\hline MSL (m) & $\sqrt{x}$ & $0.13-17.50$ & $6.64 \pm 0.53$ & $0.22-14.56$ & $6.21 \pm 0.57$ & $0.48^{\S}$ \\
\hline temperature $\left({ }^{\circ} \mathrm{C}\right)$ & $\sqrt{x}$ & $27.44-32.98$ & $29.03 \pm 0.11$ & $28.79-30.77$ & $30.06 \pm 0.07$ & $49.76^{+}$ \\
\hline salinity (ppt) & $1 / x$ & $30.35-33.60$ & $32.91 \pm 0.07$ & $21.72-32.40$ & $30.30 \pm 0.33$ & $234.15^{*}$ \\
\hline gravel (\%) & $\log x$ & $0.55-44.29$ & $10.6 \pm 1.5$ & $0.16-50.73$ & $9.3 \pm 1.4$ & $0.23^{\S}$ \\
\hline coarse sand $(\%)$ & $\log x$ & $1.88-67.00$ & $20.1 \pm 1.8$ & $0.21-43.48$ & $11.0 \pm 1.3$ & $20.78^{\ddagger}$ \\
\hline fine sand $(\%)$ & $\log x$ & $10.60-95.29$ & $66.1 \pm 2.8$ & $10.12-98.03$ & $72.8 \pm 2.4$ & $3.06^{\S}$ \\
\hline silt $(\%)$ & $\log x$ & $0.93-11.74$ & $3.19 \pm 0.21$ & $0.35-25.66$ & $6.82 \pm 0.85$ & $4.57^{\dagger}$ \\
\hline organic matter (\%) & $\log x$ & $0.88-16.62$ & $4.29 \pm 0.39$ & $0.80-24.80$ & $5.21 \pm 0.55$ & $2.28^{\S}$ \\
\hline
\end{tabular}

"Transformation; ${ }^{\dagger} p<0.01 ;{ }^{\dagger} p<0.001 ;{ }^{\S}$ no significant difference.

seasons (Table 1). Water were mixohaline (stations $3,4,5,6,7,8,12,13,14,15,19$, and 27) and euhaline (the rest of the stations) associated with river discharge.

Seasonal changes in light intensity and $K_{\mathrm{d}}$ depended on the combination of river discharge and water depth. Near the river mouth, light intensity near the sea bottom was less than $100 \mu \mathrm{mol} \mathrm{m}{ }^{-2}$ $\mathrm{s}^{-1}$ in the dry season, reaching $0 \mu \mathrm{mol} \mathrm{m} \mathrm{m}^{-2} \mathrm{~s}^{-1}$ only at station 3, where it was directly exposed to the river discharges (Fig. 2a). However, in the rainy season light levels were near $0 \mu \mathrm{mol} \mathrm{m} \mathrm{m}^{-2} \mathrm{~s}^{-1}$ at stations 3, 4, 6, 8, and 19 (Fig. 2b). Water depth ranged $0.13-17.50 \mathrm{~m}$ below mean sea level in the dry season, and $0.22-14.56 \mathrm{~m}$ below mean sea level in the rainy season; the tidal range was $1-3.5 \mathrm{~m}$ (Fig. 2c). The lowest water depth was at station $18(0.13 \mathrm{~m})$ located at the upper intertidal zone, while the deepest water depth was at station 77 $(17.50 \mathrm{~m})$ located at the north west of the island. The changes of the water depth might be a result from the sediment movement at the sea bottom, which was clearly observed in many stations during the rainy season (Fig. 2d). Salinity was also influ- (a)

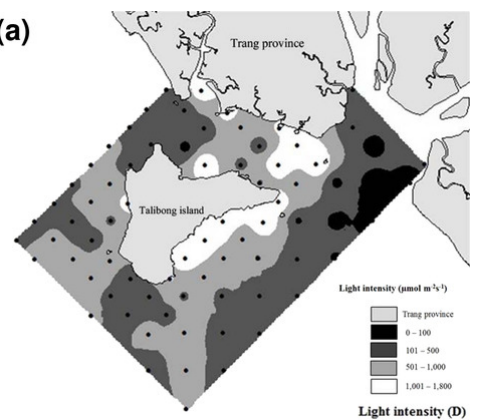

(d)

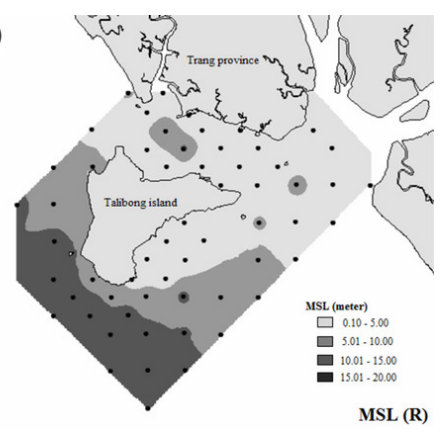

(b)

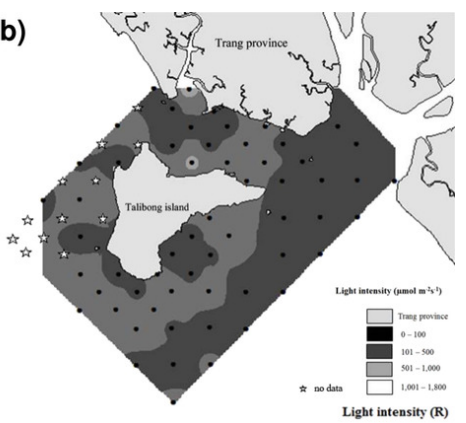

(e)

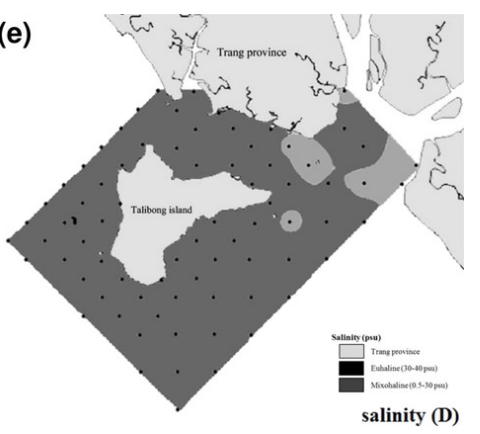

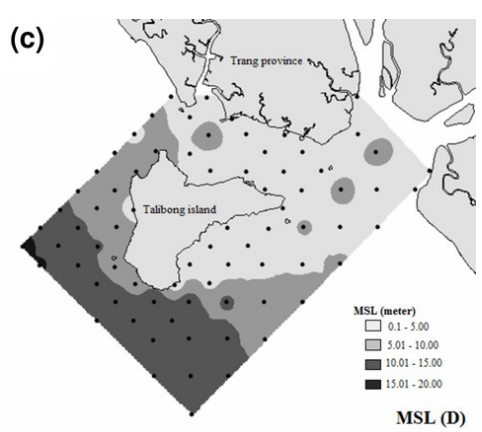

(f)

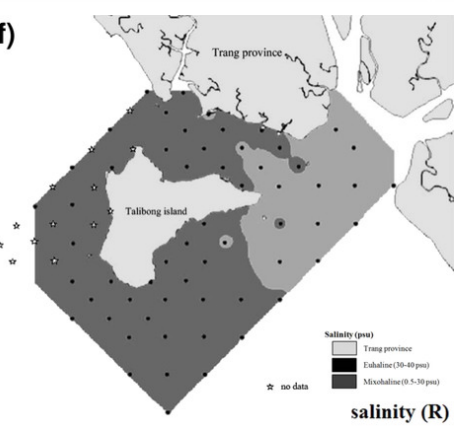

Fig. 2 Spatial distribution of physical factors: (a,b) light intensity, (c,d) MSL, and (e,f) salinity, along Trang river mouth. (D) = Dry season, $(\mathrm{R})=$ Rainy season. 
Table 2 Summary statistic for Kruskal-Wallis tests of all seagrass variables testing the effects of seagrass different species, seasons, and their interactions.

\begin{tabular}{|c|c|c|c|c|c|c|c|}
\hline Variables & SS & G & SP & $\mathrm{SS} \times \mathrm{G}$ & $\mathrm{SS} \times \mathrm{SP}$ & $\mathrm{G} \times \mathrm{SP}$ & $\mathrm{SS} \times \mathrm{G} \times \mathrm{SP}$ \\
\hline Coverage & $26.11^{*}$ & $33.11^{*}$ & 39.39 & $27.30^{\ddagger}$ & $95.76^{\ddagger}$ & $85.69^{\ddagger}$ & $224.05^{+}$ \\
\hline Density & 44.74 & $33.82^{*}$ & 29.24 & $99.83^{\star}$ & $177.17^{*}$ & $76.77^{*}$ & $243.12^{\star}$ \\
\hline Above-ground biomass & $13.05^{\ddagger}$ & $32.37^{*}$ & $88.48^{+}$ & 53.89 & $112.04^{*}$ & $137.80^{*}$ & $246.47^{*}$ \\
\hline Below-ground biomass & $11.47^{*}$ & $35.61^{*}$ & $80.87^{*}$ & $54.46^{\ddagger}$ & $113.85^{*}$ & $132.90^{*}$ & $224.68^{+}$ \\
\hline Flowering & 30.60 & $10.45^{\star}$ & $34.68^{\dagger}$ & $46.78^{\ddagger}$ & $101.40^{*}$ & $42.29^{*}$ & $263.50^{*}$ \\
\hline Fruiting & $8.76^{\dagger}$ & NS & 26.62 & 13.39 & $62.43^{\ddagger}$ & $29.49^{\dagger}$ & $229.03^{\star}$ \\
\hline
\end{tabular}

$\mathrm{SS}=$ seasons, $\mathrm{G}=$ gradients, $\mathrm{SP}=$ species; ${ }^{\dagger} p<0.01 ;{ }^{\star} p<0.001 ; \mathrm{NS}=$ no significant difference.

enced by the river discharge; water near the river mouth became brackish in the rainy season due to increased freshwater runoff (Fig. 2e,f).

\section{Seagrass distribution}

There were significant differences in cover, density, above-ground biomass, below-ground biomass, and reproduction in different species affected by gradients and seasons $(p<0.001$; Table 2$)$. Highest values of cover, density, aboveground biomass, belowground biomass, flowering, and fruiting densities were for $C$. rotundata in the mixohaline zone in the dry season (48 $\pm 12 \%)$, Halophila beccarii at euhaline in the rainy season $(280 \pm 16$ leaf pair $/ \mathrm{m}^{2}$ ), C. rotundata and E. acoroides at euhaline in the rainy season $\left(2.69 \mathrm{~g} \mathrm{DW} / \mathrm{m}^{2}\right), E$. acoroides at euhaline in the dry season $(6.45 \pm 0.92 \mathrm{~g}$ $\left.\mathrm{DW} / \mathrm{m}^{2}\right), H$. decipiens at euhaline in the rainy season $\left(18.7 \pm 7.3\right.$ flowers $\left./ \mathrm{m}^{2}\right)$, and $H$. decipiens at euhaline in the rainy season $\left(22.33 \pm 0.33\right.$ fruits $\left./ \mathrm{m}^{2}\right)$, respectively. Generally, coverage, density, aboveground biomass, below-ground biomass, and flowering were higher in euhaline $(11 \pm 1 \%, 16.5 \pm 2.8$ shoots $/ \mathrm{m}^{2}, \quad 0.44 \pm 0.05 \mathrm{~g} \mathrm{DW} / \mathrm{m}^{2}, 1.07 \pm 0.16 \mathrm{~g}$ $\mathrm{DW} / \mathrm{m}^{2}$, and $0.96 \pm 0.23$ flowers $/ \mathrm{m}^{2}$ ) than mixohaline zone $\left(4.3 \pm 1.9 \%, \quad 4.0 \pm 1.7\right.$ shoots $/ \mathrm{m}^{2}$, $0.22 \pm 0.91 \mathrm{~g} \mathrm{DW} / \mathrm{m}^{2}, 0.20 \pm 0.81 \mathrm{~g} \mathrm{DW} / \mathrm{m}^{2}$, and flowers and fruits were absent).

Ten seagrass species covered an area of $61.37 \mathrm{~km}^{2}$ around the island in the dry season (Fig. 3a). In the rainy season, eight species covered only $24.04 \mathrm{~km}^{2}$; Halophila major and Halodule
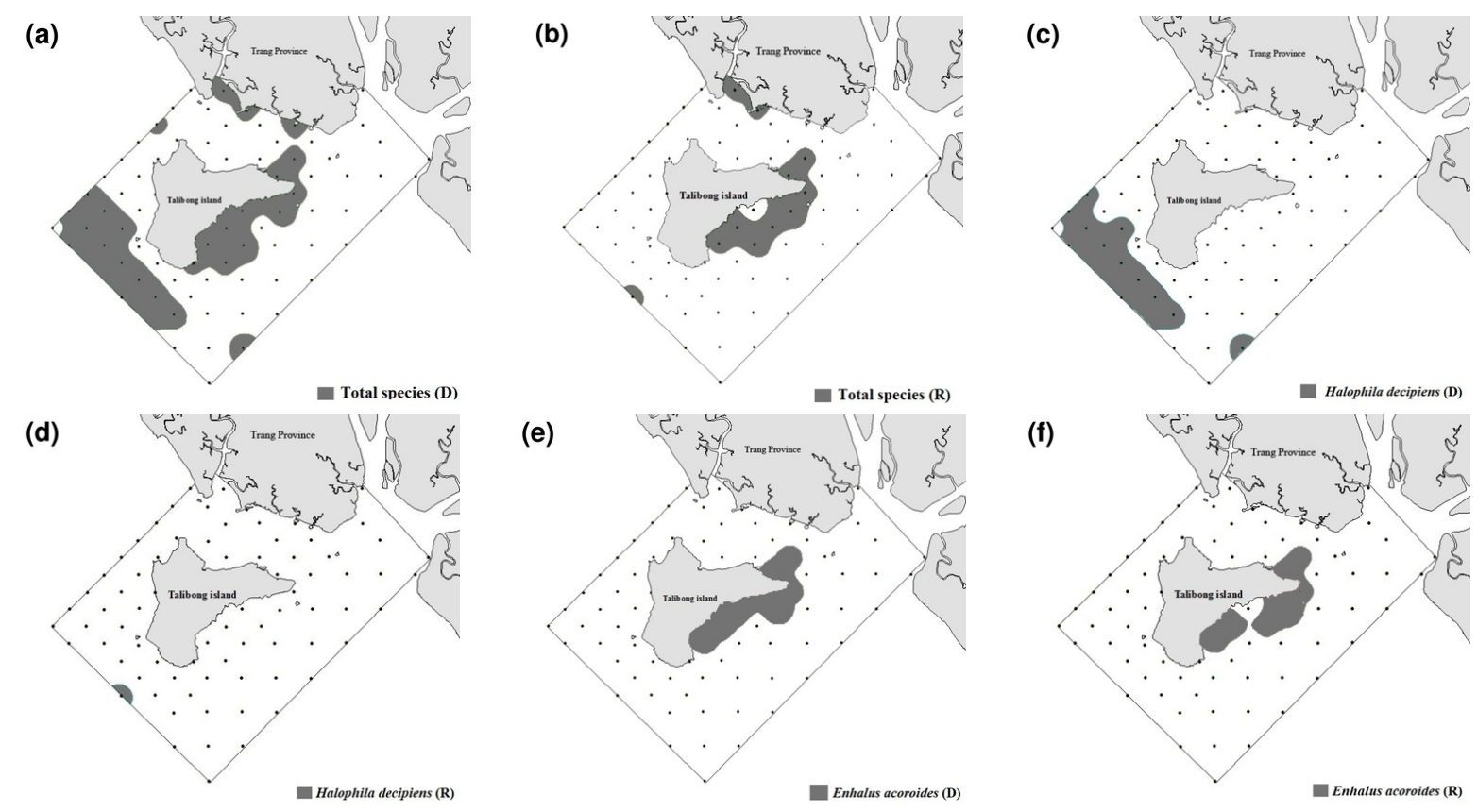

Fig. 3 Distribution of the ten seagrass species from 77 sampling stations along Trang river mouth: (a,b) total seagrass species; (c,d) H. decipiens; (e,f) E. acoroides; (g,h) H. ovalis; (i,j) C. rotundata; (k,l) C. serrulata; (m,n) T. hemprichii; (o,p) H. beccarii; (q) H. major; (r) H. pinifolia. (D) = Dry season, (R) = Rainy season. 


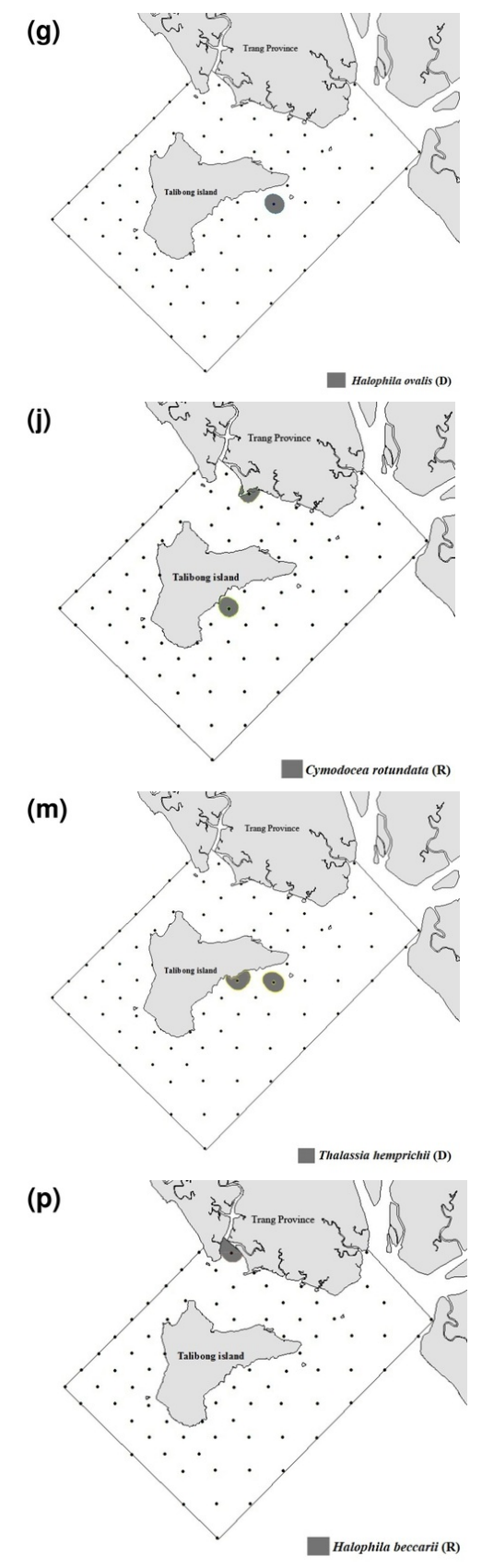

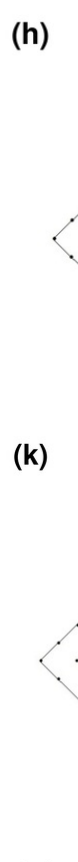
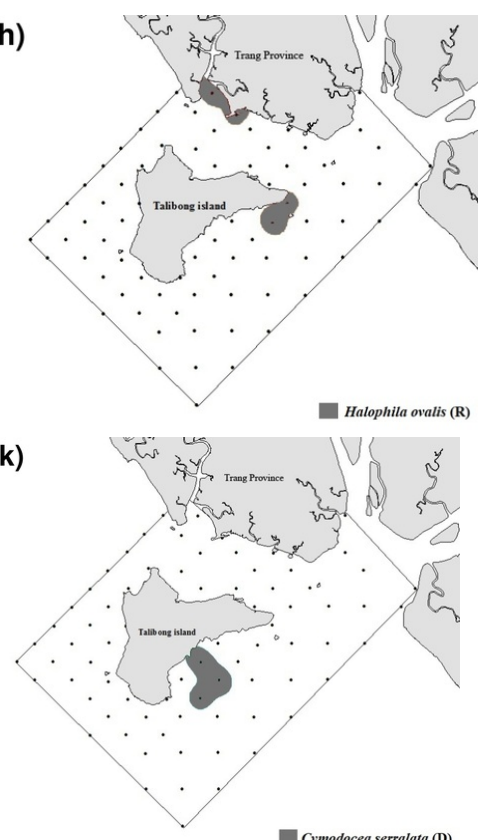

(n)

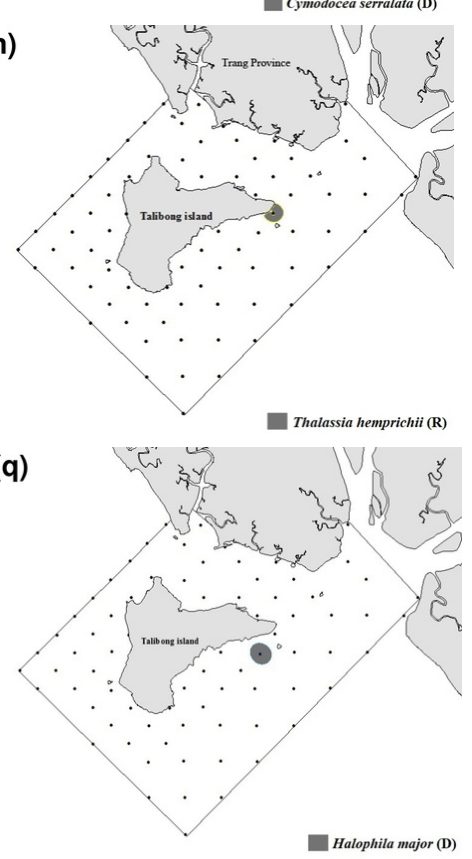

(i)

(l)
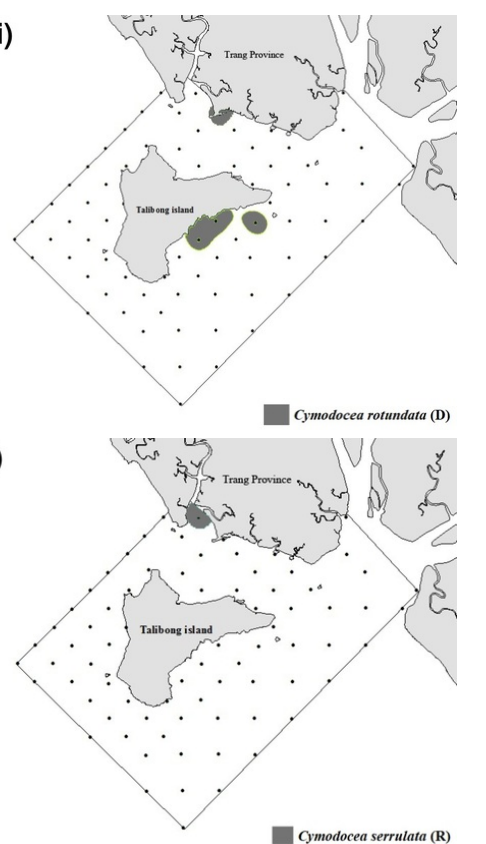

(o)

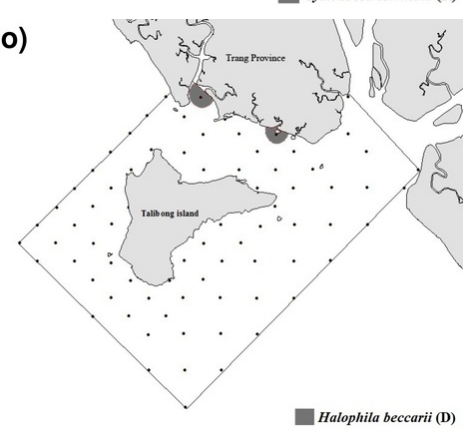

(r)

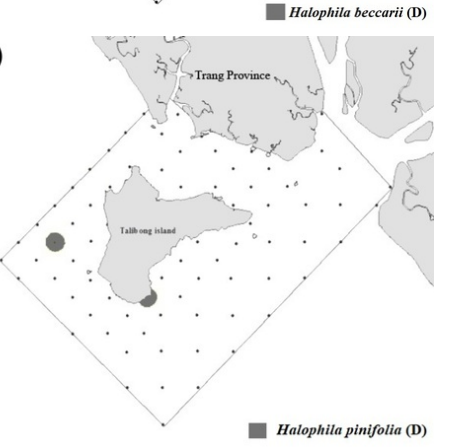

Fig. 3 (Continued).

pinifolia were absent in the rainy season (Fig. 3b). $H$. decipiens was the most widely distributed species, covering $28.55 \mathrm{~km}^{2}$ in the dry season (Fig. 3c); but only $0.88 \mathrm{~km}^{2}$ in the rainy season (Fig. 3d). As expected, E. acoroides was not influenced by season, covered $15.87 \mathrm{~km}^{2}$ in both seasons (Fig. 3e,f). H. ovalis covered $12.60 \mathrm{~km}^{2}$ in the dry (Fig. 3g) and only $6.96 \mathrm{~km}^{2}$ in the rainy season (Fig. $3 \mathrm{~h}$ ). In addition, C. rotundata, C. serrulata, T. hemprichii,
$H$. beccarii, Halodule uninervis, $H$. major, and $H$. pinifolia were observed in this study (Fig. 3i-r), but they were less abundant and varied between seasons.

Relationship between environmental factors and species distribution

There was a significant relationship between species distribution and physical and chemical parameters ( $p<0.01$; the explained variance of Axis $1=$ 
Table 3 Partial correlation coefficients of the effects of environmental parameters on coverage, density, above-ground biomass, and below-ground biomass of significant seagrass species.

\begin{tabular}{llcccccccc}
\hline Variable & Species & Constant & Depth & Temp. & Sal. & df & $F$ & $R^{2}$ & $p$-value \\
\hline Coverage & E. acoroides & 1.10 & 6.92 & NS & NS & 38 & 6.71 & 0.15 & $<0.05$ \\
& H. ovalis & -7.04 & NS & NS & NS & 21 & 5.37 & 0.21 & $<0.05$ \\
& C. rotundata & 78.19 & NS & NS & NS & 13 & 1.93 & 0.62 & $<0.01$ \\
& H. decipiens & 0.36 & 4.21 & NS & NS & 42 & 4.54 & 0.10 & $<0.05$ \\
Density & H. decipiens & 2.81 & 37.20 & NS & NS & 42 & 510 & 0.11 & $<0.05$ \\
Above-ground biomass & E. acoroides & 1.60 & 1.97 & NS & NS & 38 & 8.41 & 0.19 & $<0.01$ \\
& C. rotundata & 30.22 & 2.69 & NS & NS & 13 & 11.23 & 0.67 & $<0.01$ \\
& H. decipiens & 0.12 & 0.04 & NS & NS & 42 & 5.91 & 0.13 & $<0.05$ \\
Below-ground biomass & E. acoroides & -24.41 & NS & NS & 26.98 & 38 & 5.74 & 0.13 & $<0.01$ \\
& T. hemprichii & -54.71 & NS & 41.41 & NS & 3 & 23.1 & 0.92 & $<0.05$ \\
& C. rotundata & 10.76 & NS & NS & NS & 13 & 7.69 & 0.39 & $<0.05$ \\
Flowering & H. decipiens & -0.24 & NS & 0.19 & NS & 42 & 5.61 & 0.12 & $<0.05$ \\
Fruiting & H. decipiens & 22.27 & NS & -13.19 & NS & 42 & 9.45 & 0.19 & $<0.05$ \\
\hline & H. decipiens & 12.91 & -4.19 & NS & NS & 42 & 14.34 & 0.26 & $<0.01$ \\
\hline
\end{tabular}

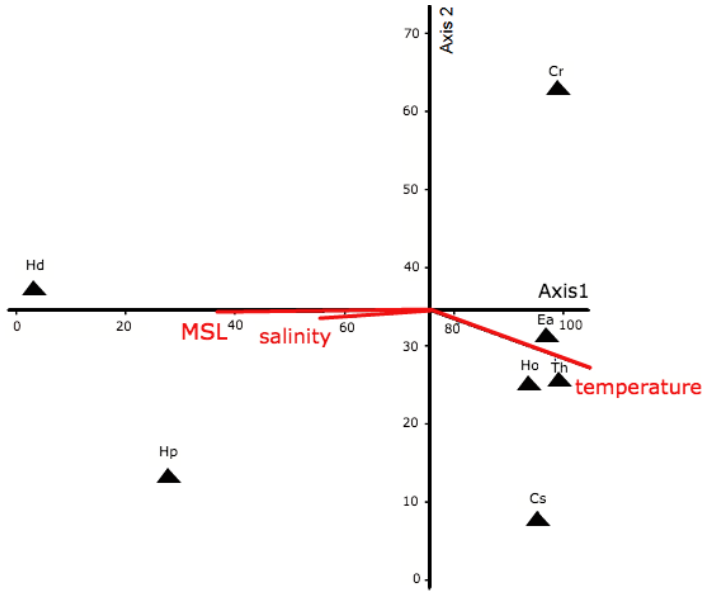

Fig. 4 CCA biplot of analysis for the seagrass distribution versus physical parameters: species codes: Ea (E. acoroides); Ho (H. ovalis); Hp (H. pinifolia); Hd (H. decipiens); Th (T. hemprichii); Cr (C. rotundata); and Cs (C. serrulata). Environment parameter codes: MSL (mean sea level), salinity, and temperature.

$22 \%$ and Axis $2=12 \%$ ). Only Halophila decipiens was associated with increasing mean sea level (MSL) and salinity, while E. acoroides, $H$. ovalis, and T. hemprichii had a positive relation with temperature (Fig. 4).

The stepwise multiple regressions showed that there were relationships, but these varied among species between plants and physical and chemical parameters (Table 3). Percentage cover and above-ground biomass of E. acoroides and Halophila decipiens, for example, were positively correlated with water depth, while below-ground biomass of E. acoroides was positively correlated with salinity. Below-ground biomass of $T$. hemprichii had a positive relationship with temperature. $H$. decipiens was the only species influenced by various physical conditions, including their flowering and fruits density.

\section{DISCUSSION}

Light intensity, MSL, and salinity showed gradients from Trang river mouth to the open sea, increasing with the distance from the river mouth. Coverage, density, biomass, and reproduction in most seagrass species were significant higher in euhaline than in mixohaline zones. Most species showed negative correlation with salinity as suggested by the CCA, but there were no clear relationships between biological parameters and salinity except the belowground biomass of $E$. acoroides, which increased with increasing salinity. Salinity did not affect the biomass and cover of the standing seagrasses, possibly because these occurred in lower tidal or subtidal areas and were thus little exposed to waters with reduced salinity. E. acoroides was the exception, showing decreased below-ground biomass with reduced salinity, but, in contrast with other seagrasses, this species persisted in areas near the river mouth, including during the rainy season.

$H$. decipiens was the most widely distributed species, covering $28.55 \mathrm{~km}^{2}$ in the dry season but only $0.88 \mathrm{~km}^{2}$ in the rainy season. $H$. decipiens is a low-light species, which can grow in range 15$58 \mathrm{~m}$ depth in clear water ${ }^{16}$; here it occurred at 
10-15 m depth. This species has a short life span and grows only a few months and produces seeds, which are buried in the sediment ${ }^{17,18}$. In our study, there were some seedlings observed in November 2014 during the transition month from rainy to dry season, however they were washed away after 23 days, during a short period when sand drifted and strong wave occurred. Also, large $H$. decipiens mats were often washed up on the shore during the rainy season. This species has not been previously reported or observed at our site $e^{7,19}$. The recent occurrence of $H$. decipiens might be a result from the tsunami in 2004, when the area was hit by the high waves and the sediment movements changed the macrophyte community at the site ${ }^{20}$. In south Florida, $H$. decipiens was also the dominant species which covered $7500 \mathrm{~km}^{2}$ from $17000 \mathrm{~km}^{2}$ survey area ${ }^{21}$. Although $H$. decipiens beds supported fewer marine animals than intertidal seagrass beds, the productivity of depth beds is often high, which is important for epibenthic fauna ${ }^{22}$.

There were differences in physical and chemical parameters between dry and rainy seasons. Salinity ranged 30.54-33.76 psu classified as euhaline sea in the dry season, while in the rainy season the salinity ranged $21.80-32.55$ psu. Light intensity and $K_{\mathrm{d}}$ strongly decreased in the rainy season when underwater light intensity was less than $100 \mu \mathrm{mol}$ $\mathrm{m}^{-2} \mathrm{~s}^{-1}$ in many stations near the river mouth. Abundance of the seagrasses at our study was much lower than at the nearby Hat Chao Mai National Park, a pristine site only $12 \mathrm{~km}$ away from the site. For example, the biomass of $H$. ovalis, T. hemprichii, and $C$. rotundata were only $223 \pm 57$ shoot $/ \mathrm{m}^{2}$, 12 shoot $/ \mathrm{m}^{2}$, and $72 \pm 27$ shoot $/ \mathrm{m}^{2}$ compared to $5823 \pm 745$ shoot $/ \mathrm{m}^{2}, 1249 \pm 75 \mathrm{shoot} / \mathrm{m}^{2}$, and $1525 \pm 88$ shoot $/ \mathrm{m}^{2}$, respectively ${ }^{23}$. This difference in abundance most likely can be attributed to the environment at our study sites exposing the seagrasses to lower salinity, light stress, and high sedimentation. The sediment runoff did not only limit light availability but also could directly bury the small species as we often observed that $H$. beccarii, $H$. uninervis, $H$. major, and $H$. pinifolia were partially covered by the sediment; and $H$. decipiens which occurred in the deeper water was sometimes completely buried. Although larger species were not buried by the sediment, their photosynthesis might be limited by lower light intensity, which resulted in lower biomass. The largest species in the tropic, E. acoroides, seems to be the most tolerant species against the siltation as documented in a few studies of extensive coastal developments in the South East
Asian region ${ }^{7,24}$.

Flowering was only observed in E. acoroides, $H$. ovalis, and $H$. decipiens; and only $H$. decipiens developed fruits in the dry season. Generally, $E$. acoroides reproduces throughout the year, but we have found that they only reproduced during the dry season at our site. Flowering frequency at our riverine-influenced study site (0.003) was also lower than at the nearby marine site $(0.1)$, where plants are not influenced by the salinity changes or associated with the sedimentation from the river mouth ${ }^{25}$. H. ovalis also reproduced flowers in the dry season, although in other areas it produces throughout the year ${ }^{26}$. A recent laboratory study, demonstrated that reproductive potential of $H$. ovalis decreased at lower salinity, dying at 3$6 \mathrm{psu}^{13}$. Percentage cover and fruiting of $H$. decipiens $\left(1.8 \pm 0.7 \%\right.$ and $0.35 \pm 0.25$ flowers $\left./ \mathrm{m}^{2}\right)$ were also much lower than previously reported in Chumphon province, Gulf of Thailand $(46.7 \pm 6.1$ and $35 \pm 14$ fruit $\left./ \mathrm{m}^{2}\right)^{17}$, although it was the only species for which plants developed seeds.

Global climate change, resulting in uncertain seasonal local climate, may affect the tropical seagrasses in estuarine environments. Especially, decrease in light availability with increasing fresh water runoff plays an essential role in the persistence of the seagrasses, with salinity playing a less important role. In this region, where coastal developments are intensive, such unpredicted scenario could cause a lot of sediment runoff and this could be the major cause to limit growth and reproduction of seagrasses. Increasing $\mathrm{CO}_{2}$ and lower $\mathrm{pH}$ are also consequences of global climate changes, and these most likely do not affect the physiology of seagrasses ${ }^{27}$, but awareness should be raised of the other consequences of global climate change as that mentioned in this study (increased terrestrial runoff).

Acknowledgements: This work was supported in part by the National Research University and the Graduate School, Prince of Songkla University, Thailand, Asian CORE Programme and core to core Programme of the Japan Society for the Promotion of Science to CK, and Grant No. SCI560300S to AP. We would like to thank the Seaweed and Seagrass Research Unit Team, Prince of Songkla University and Marine National Park Education Centre in Trang, for support during field trip collections. We are grateful to Nongphanga Thitinantapan, Rachakorn Sirijarukul, and Panu Jarulakkhana who helped with the field trip collections; and Milica Stankovic helped with mapping. 


\section{REFERENCES}

1. Short FT, Wyllie-Echeverria S (1996) Natural and human induced disturbance in seagrass. Environ Conservat 23, 17-27.

2. Freeman AS, Short FT, Isnain I, Razak FA, Coles RG (2008) Seagrass on the edge: Land-use practices threaten coastal seagrass communities in Sabah, Malaysia. Biol Conservat 141, 2993-3005.

3. Kamp-Nielsen L, Vermaat JE, Wesseling I, Borum J, Geertz-Hansen O (2002) Sediment proportion along gradients of siltation in South-east Asia. Estuar Coast Shelf Sci 54, 127-37.

4. Cabaço S, Santos R (2007) Effects of burial and erosion on the seagrass Zostera noltii. J Exp Mar Biol Ecol 340, 204-12.

5. Short FT, Carruthers T, Dennison W, Waycott M (2007) Global seagrass distribution and diversity: A bioregional model. J Exp Mar Biol Ecol 350, 3-20.

6. Nakaoka M, Tanaka Y, Watanabe M (2004) Species diversity and abundance of seagrasses in southwestern Thailand under different influence of river discharge. Coast Mar Sci 29, 75-80.

7. Terrados J, Duarte CM, Fortes MD, Borum J, Agawin NSR, Bach S, Thampanya U, Kamp-Nielsen L, et al (1998) Changes in community structure and biomass of seagrass communities along gradients of siltation in SE Asia. Estuar Coast Shelf Sci 46, 757-68.

8. Gillanders BM, Kingsford MJ (2002) Impact of changes in flow of freshwater on estuarine and open coastal habitats and the associated organisms. In: Gibson RN, Barnes M, Atkinson RJA (eds) Oceanography and Marine Biology: an Annual Review, vol 40, Taylor \& Francis, London, pp 233-309.

9. Milliman JD, Meade RH (1983) World-wide delivery of river sediment to the oceans. J Geol 91, 1-21.

10. National Hydro Informatics and Climate Data Center (2017) Flood History, Hydro and Agro Informatics Institute, Bangkok.

11. Nakanishi Y, Hosoya S, Nakanishi Y, Arai N, Adulyanukosol K (2005) The distribution of dugong trenches in the seagrass beds of Libong Island, Thailand. $J$ Adv Mar Sci Tech Soc 11(1), 53-7, [in Japanese].

12. Touchette BW (2007) Seagrass-salinity interactions: physiological mechanisms used by submersed marine angiosperms for a life at sea. J Exp Mar Biol Ecol 350, 194-215.

13. Collier CJ, Villacorta-Rath C, van Dijk K-j, Takahashi M, Waycott M (2014) Seagrass proliferation precedes mortality during hypo-salinity events: A stress-induced morphometric response. PLoS One 9 , e94014.

14. Flemming BW (2000) A revised textural classification of gravel-free muddy sediments on the basis of ternary diagrams. Continent Shelf Res 20, 1125-37.

15. Heiri O, Lotter AF, Lemcke G (2001) Loss on ignition as a method for estimating organic and carbonate content in sediments: reproducibility and comparability of results. $J$ Paleolimnol 25, 101-10.

16. Carruthers TJB, Dennison WC, Longstaff BJ, Waycott M, Abal EG, McKenzie LJ, Lee Long WJ (2002) Seagrass habitats of northeast Australia: models of key processes and controls. Bull Mar Sci 71, 1153-69.

17. Rattnachot E, Tantiprapas P, Wichachucherd B, Prathep A (2008) Seasonal variation in coverage, canopy height, fruit density and biomass of subtidal seagrass Halophila decipeins Ostenfeld in Chumphon Coast, The Gulf of Thailand. In: Proceedings of the 6th IMT-GT UNINET Conference, Penang, Malaysia, 28-30 August, 2008, pp 334-8.

18. Josselyn M, Fonseca M, Niesen T, Larson R (1986) Biomass, Production and decomposition of a depth water seagrass, Halophila decipiens Ostenf. Aquat Bot 25, 47-61.

19. Rattanachot E, Short FT, Prathep A (2016) Enhalus acoroides responses to experimental shoot density reductions in Haad Chao Mai National Park, Trang Province, Thailand. Mar Ecol 37, 411-8.

20. Prathep A, Mayakun J, Tantiprapas P, Darakrai A (2008) Can macroalgae recover, 13 months after the 2004 Tsunami? A case study at Talibong Island, Trang Province, Thailand. J Appl Phycol 20, 907-14.

21. Fourqurean JW, Willsie AW, Rose CD, Rutten LM (2001) Spatial and temporal pattern in seagrass community compositionand productivity in south Florida. Mar Biol 138, 341-54.

22. Erftmeijer PLA, Stapel J (1999) Primary production of deep-water Halophila ovalis meadows. Aquat Bot 65, 71-82.

23. Rattanachot E, Prathep A (2015) Species specific effects of three morphologically different belowground seagrasses on sediment properties. Estuar Coast Shelf Sci 167, 427-35.

24. Duarte CM, Terrados J, Agawin NSR, Fortes MD, Bach S, Kenworthy WJ (1997) Response of a mixed Philippine seagrass meadow to experimental burial. Mar Ecol Progr Ser 147, 285-94.

25. Rattanachot E, Prathep A (2011) Temporal variation in growth and reproduction of Enhalus acoroides (L.f.) Royle in a monospecific meadow in Haad Chao Mai National Park, Trang Province, Thailand. Bot Mar 54, 201-7.

26. den Hartog C (1970) The Sea-Grasses of the World, Verhandelingen der Koninklijke Nederlandse Akademie van Wetenschappen, Afd. Natuurkunde II, vol 59, North-Holland Publ. Co., Amsterdam.

27. Björk M, Short F, McLeod E, Beers S (2008) Managing Seagrasses for Resilience to Climate Change, IUCN, Gland, Switzerland. 